\title{
EFL Students Perception on Mendeley Reference Manager in Thesis Writing
}

\author{
Ariyanti ${ }^{1}$, Rinda Fitriana ${ }^{2}$ \\ \{ariyanti.muflihin@gmail.com ${ }^{1}$, rindming@gmail.com ${ }^{2}$ \} \\ ${ }^{1,2}$ University of Widya Gama Mahakam, J1. K. H. Wahid Hasyim No. 28 Samarinda, East Borneo
}

\begin{abstract}
This research is aimed investigate perception of EFL students in using Mendeley to help them in thesis writing. The sample of this research consist of 53 students from three different majors in Faculty of Teacher Training and Education, namely English Language Teaching, Primary Teaching, and Early-Childhood Teaching Majors. This is a survey study where the researchers distributed questionnaire to the EFL students in the context of University of Widya Gama Mahakam Samarinda who have graduated in 2018. In addition, quantitative approach is used in this research by the existence of frequency distribution analysis of each indicator exist on the questionnaire. As a result, most of students are assisted by features provided by Mendeley especially the easeness in terms of quoting and referencing. It is indicated by the result showed from items existed in the questionnaired stated that whether Mendeley eases them to cite and build references for up to $85 \%$. Students' barriers in using Mendeley in their thesis are discussed further as well as the future implication regarding with the area of study.
\end{abstract}

Keywords: Mendeley Reference Manager, Quoting and Referencing, Thesis Writing, EFL Students' Perception.

\section{Introduction}

In this millenial era, English is still considered as an important language to be mastered by people. Specifically for students, especially in the context of English as a Foreign Language, English is a must to study since in lower level of education. Furthermore, to the context of college education, especially for English department students, they still need to struggle to learn English in order to have a good learning achievement. Finally, when they are already in the fourth year, they start to accomplish a thesis as a requirement to finish their study at university. In general, Mendeley is used by many people with different background, such as Teacher Training and Education, Medical area, etc. It is because Mendeley can be used to help people to ease their works especially in paper accomplishment. As an example, Russo et al. [1] whose major is from Madical Health explored and shared about Mendeley as a tool to ease people to read references, cite them, and write bibliography in articles. Furthermore, there are many research that have studied about Mendeley Reference Manager. The first research is from Butros $\&$ Taylor [2], where in their research, they focus to investigate advantages and disadvantages of using several reference managers i.e. Mendeley, Zotero, RefWorks, and EndNote. In short, they make some comparison among those reference managers including information about featured offered for readers. 
Unlike Butros \& Taylor, Haustein \& Larivière [3] investigate the use of Mendeley as a source for academic people such as students of Post Graduate and Doctoral students to read many references. In their research they also investigate the correlation between tendency of reading references from Mendeley as well as citing them in their working paper. As a result, they found that the reading frequency by using Mendeley is significant and there is positive correlation between the students' ready frequency and citing activities towards those references. Not only Haustein \& Larivière, Zahedi, Haustein, \& Bowman [4] and Maflahi \& Thelwall [5] also investigate about Mendeley as a media to read many sources. Specifically, Zahedi, Haustein, \& Bowman [4] and Maflahi \& Thelwall [5] found out the frequency of reading by people by using readership count via manual search from Mendeley catalog. In addition, Maflahi \& Thelwall [5] add that Mendeley reader counts is an evolution in academic and research area in order to investigate how articles being cited since they are posted or publishhed. It becomes important because there are two indicators of labeling academicians as an active researcher, firstly is how many papers they produce and publish, and secondly is how many research have cited their articles.

Among above previous studies, none of them studied about Mendeley as a tool to help students in writing their thesis. Specifically, in Indonesian colleges, accomplishing a thesis is a requirement for students to finish their study at a university. In writing thesis, college students often spend a long time, even until seventh year of study at college because they are stuck in compiling it. Regarding with this matter, of course they may face difficulties in thesis writing. Particularly, the researchers conducted a research about the use of Mendeley reference manager to help college students in accomplishing their thesis in the context of University of Widya Gama Mahakam Samarinda, East Kalimantan, Indonesia. Specifically in Faculty of Teacher Training and Education at the University, the Dean has made an obligation for students of three majors existed in the Faculty, namely English Language Education, Early Childhood Teaching, and Primary Teaching Majors to follow. The obligation is that every student in fourth semester should complie their thesis by using Mendeley to quote theories from expert and write references from the sources which have been quoted.

Moreover, above condition appears based on problems the students face when writing a thesis. There are several problems appear in thesis accomplished by students at the Faculty of Teacher Training and Education at University of Widya Gama Mahakam Samarinda for many years. The first problem is sources the students use to write their thesis are not propered, for example, online sources from Wikipedia and Blogspot. In this case, everyone can upload their articles on Wikipedia while other people can also edit those articles. The same case for Blogspot, many people with different background, or even student of lower level of education can have their own Blog. Another problem is miswriting when citing sources on their thesis. For example, in one of citation styles, American Psychology Association, when quoting theories of a expert, we just need to mention the last name of the author, not the full name. The fact is that many students still put the full name of the author when citing their theories in the literature of their thesis. Lastly the problem that almost always occur is students missed to write references from certain sources that they have quoted in their thesis. It happened because they do quoting and referencing in traditional or manual method. Therefore, by the existence of Mendeley reference manager, the Dean of Faculty of Teacher Training of Education at University of Widya Gama Mahakam Samarinda expect that the obligation of using Mendeley in accomplishing their thesis can help them in terms of citing and referencing, especially to upgrade the quality of theses produced at the University.

As above obligation in thesis writing has been applied since 2018, and the students in that year have graduate from University of Widya Gama Mahakam Samarinda, the researchers 
conducted a former research regarding with those students' perception in using Mendeley in their project of thesis writing. Word document can be used as a template for papers to be published in EAI Proceedings. Follow the text for further instructions on text formating, tables, figures, citations and references.

\section{Review of Literatures Concept of Mendeley as a Reference Manager}

\subsection{The Concept of Mendeley as a Reference Manager}

Mendeley is one of reference managers existed since 2007 which was found by three University students in Germany, until finally being bought by Elsevier, an International and famous publisher in 2013. Mendeley is design in two platforms, i.e. online platform that can be accessed via official website of Mendeley (www.mendeley.com) and offline platform or what so called by Mendeley Desktop. Mendeley develop its system based on three priciples, they are reference management, social networking, and research data [6]. Specifically, reference management means researchers can manage their articles in terms of method of citing theories from experts and writing references from the sources being quoted. In addition, by using Mendeley, we can cooperate and colaborate with other researchers who join the Mendeley. In this canse, we can find out people or researchers to colaborate in accomplishing a research. We can also join groups provided in Mendeley online version by browsing kinds of groups that we need and relevant to our area of research. Lastly, Mendeley is a software which can save metadata and become a source for readers to cite any research.

Moreover, in order to help researchers and students to use Mendeley in their articles and theses, they need to understand features of Mendeley whether in online or offline versions, they are Mendeley online include Expand Networking, Feed, My Library, Suggest, Groups, Careers, Funding, Settings \& Privacy, Mendeley Advisor, Mendeley Premium. Meanwhile, features on Mendeley offline include My Library, Create Folder, Fikter Database, Add Files, Add Folder, Literature Search, Citation Style, Add Entry Manually, Synchronize, Favorite Files, Membaca File PDF, Unsorted Database, Needs Review, Export \& Import Files, Mendeley Directory Setting [7].

\subsection{The Reasons Why Mendeley Appears as Solution in Article and Thesis Writing}

Mendeley is a software which function is to help researchers and students in the level of University in doing their research. Specifically, Mendeley as one of reference managers appear based on phenomenon happened in the area of accomplishing an article by researchers, and thesis by university students. The phenomenon happened is alike with the problems occurs when accomplishing working papers as mentioned by the researchers on the previous point, which is in the Introduction part. Reference managers e.g. Mendeley, appears because of problems occurred in education life especially in the area of research or thesis writing [7]. Firstly, the action of plagiarism among students. This condition appears because of an action of plagiarism where students do not mention the name of experts which theories they use or quote in their thesis or research. In addition, the phenomenon happened is that many students read contain of certain paper owned by an expert, then they write it on their paper and make it as their own idea. Secondly, miss writing when quoting the name of experts. For example, in APA style, when quoting an expert's theory, we just need to mention the last name of the expert. The matter of fact, there are still many researchers and also students mention full name of the expert. By using Mendeley, we can choose the citation style, and the way of citing the theory from expert can be 
arranged automatically. The last point that becomes a problem in this case is researchers or students forget to mention references they have quoted on their article or thesis. This problem is one of priorities that Mendeley tried to solve. By clicking "Insert Bibliography" botton on the Ms Word, all of sources that we have quoted on the body of our articles or theses will be mentioned one by one authomatically and systematically. Furthermore, by using Mendeley as a reference manager, we can save our time to manage our writing project [10]. The real example of why Mendeley can be very useful in saving our time is from the writing of references. In this case, when we do our writing manually, it will take much time and will not effective for avoid the mistakes in spelling, space, alphabeticall arrangement, etc. Fortunately, we will not bother too much to do that wasting time activity because by clicking one button of "Insert Bibliography“, Mendeley will show the references authomatically based on the style that we have chosen.

The existence of mendeley can solve the issue of plagiarism among researchers and students [8]. Particularly, the matter of plagiarism occurs because of online sources which provided on internet browser. Nowadays, people can find many online sources which are open access. Meaning that people can access and download without giving any charge to buy the materials or sources on the online platform.

Not only the issue of plagiarism, the existence of Mendeley can teach people who are in needs to manage and backup files such as name of author, year of publication, book title, publishing city, and publisher. In addition, we will also can choose citation style, as well as building social networks [9]. Since Mendeley is used by many scientist to post their works on Mendeley online version, they can interact one to another by having and joining groups which are relevant to their area of research interest.

\section{Research Methodology}

This research is a survey study with quantitative approach where the researchers figure out the perception of the fourth year students at University of Widya Gama Mahakam Samarinda related to the use of Mendeley reference manager in their thesis writing. The population of the study consist of all of students who have graduated in 2018 where they did their thesis by using Mendeley. The total number of the students are 134 students from three majors existed in the Faculty of Teacher Training and Education at University of Widya Gama Mahakam Samarinda, i.e. English Language Education, Early-Childhood Teaching, and Primary Teaching majors. However, only 53 participants responded the questionnaire through www.surveymonkey.com. The researchers took them all as the sample of this survey study as well as giving them a questionnaire to fill out. Basically, the items of questionnaire aim to investigate the students' perception toward the use of Mendeley in their study. Regarding with the items of questionnaire used in this study, the researchers provide it by themselves because there is no previous research that the researchers could find studied about the perception of the use of Mendeley reference manager.

Regarding with the data collecting and analysis techniques, the researchers administered seven items of questionnaire via www.surveymonkey.com to all of mentioned students above as they have graduated from the University and many of them are from towns which out of Samarinda. Having administered the questionaire, the researchers tabulated the result by using frequency distribution analysis. In addition, the researchers also count the mean of each indicator existed in the questionaire. 


\section{Findings and Discussion}

\subsection{Findings}

The questionnaire we administered was in form of yes/no questions and delivered to participants via surveymonkey.com. There are ten questions related the frequency of students using Mendeley, students' challenges in applying Mendeley, the easiness of using Mendeley compared with manual citation, and the stakeholder support on Mendeley utilization. It is important to note that this study only focuses on the use of Mendeley for bachelor thesis. In general, the findings can be summarized in the following figure;

\begin{tabular}{|c|c|c|c|}
\hline \multicolumn{4}{|c|}{$\square$ yes $\square$ no } \\
\hline 一 & $\begin{array}{l}\text { Do you use Mendeley for writing references in } \\
\text { your thesis? }\end{array}$ & $7,55 \%$ & $92,45 \%$ \\
\hline$N$ & $\begin{array}{l}\text { Do you use Mendeley for citatation in your } \\
\text { thesis? }\end{array}$ & $9,43 \%$ & $90,57 \%$ \\
\hline$m$ & $\begin{array}{l}\text { Do you have difficulties in using Mendeley for } \\
\text { you thesis? }\end{array}$ & $25,00 \%$ & $75,00 \%$ \\
\hline & $\begin{array}{l}\text { Does your computer specification support for } \\
\text { running Mendeley software? }\end{array}$ & $17,31 \%$ & $82,69 \%$ \\
\hline$n$ & $\begin{array}{l}\text { Does the office software program in your laptop } \\
\text { support the use of Mendeley? }\end{array}$ & $15,69 \%$ & $84,31 \%$ \\
\hline 6 & $\begin{array}{l}\text { Are you lack of understanding towards the } \\
\text { technical use of Mendeley? }\end{array}$ & $17,31 \%$ & $82,69 \%$ \\
\hline$r$ & $\begin{array}{l}\text { I do not have laptop so I have to borrow it from } \\
\text { my friends }\end{array}$ & $11,54 \%$ & $88,46 \%$ \\
\hline$\infty$ & $\begin{array}{l}\text { Do you think using it is easier to cite theories by } \\
\text { using Mendeley compared with manually? }\end{array}$ & $11,54 \%$ & $88,46 \%$ \\
\hline$a$ & $\begin{array}{l}\text { Do you think it is easier to write references by } \\
\text { using Mendeley rather than writing them... }\end{array}$ & $11,54 \%$ & $88,46 \%$ \\
\hline 으 & $\begin{array}{l}\text { Does your campus support you for using } \\
\text { Mendeley, such as carrying out workshop for.. }\end{array}$ & $0,00 \%$ & $100,00 \%$ \\
\hline
\end{tabular}

Fig. 1. Questionnaire Result

First, regarding with how frequent students use Mendeley, $90.57 \%$ admitted that they used Mendeley to cite theories in their thesis and $92.45 \%$ said they applied Mendeley to write their refererences for their thesis.

Second, in terms of difficulties encountered during applying Mendeley for their thesis, $25 \%$ found it hard to use Mendeley when they citing theories and writing references. The challenges refer to inadequate computer specification that does not support for running Mendeley software $(17.31 \%)$. Still related to computer issue, $15.69 \%$ admitted that their office software does not support for Mendeley software. On the other hand, $17.31 \%$ participant still do not understand how to use Mendeley technically. In addition, $11.54 \%$ participants do not have their own personal computer that make them difficult to use Mendeley since they have to borrow it from 
their friends. In brief, the biggest challenge that students encouter when using Mendeley is due to technical issue, such as low computer specification.

Regarding to the easiness of using Mendeley, $88.46 \%$ participants believed that it is easier to use Mendeley to cite theories compared with manual citation. Similarly, $88.48 \%$ participants stated that writing references are much easier when using Mendeley, compared with when they write the references manually.

Since applying Mendeley for citation and writing references in students' final project (thesis) is an obligation, the faculty and university supports the students by carrying out workshops on the technical use of Mendeley as well as the application for thesis writing, which admitted by all participant.

\subsection{Discussion}

From previous studies explained previously in introduction, many of research on Mendeley were not done in context of Indonesia. Meaning that with different context, there must be different condition and different students or participants. In this case, we can interpret that several reserachers use Mendeley as a media of collecting and reading a lot of sources for students [3][5][4], even though other research also use Mendeley to cite theories and build references [1]. Meanwhile, another researcher still focus on comparing the advantages of using several reference managers such as Mendeley, Zotero, EndNote, and RefWorks [2].

However, none of above previous studies investigated the use of Mendeley to help bachelor students in citing theories as well as writing references in their thesis. Regarding with this research, the researchers found that despite the fact that the university has $100 \%$ support by providing Mendeley workshop for students, there are less than $10 \%$ who still did not use Mendeley in accomplishing their thesis. The researchers believe that it is correlated to some aspects mentioned on the questionnaire such as students still face difficulties in using Mendeley (25\%), unsupported program of Mendeley in their laptop (15.69\%), low computer specification $(17.31 \%)$, and lack of understanding towards the use of Mendeley $(17.31 \%)$.

Inspite above 'negative result' appear, most of the students follow the regulation of using Mendeley for their thesis writing. In addition, most of them argue that by the use of Mendeley, they feel it is easier to for them to do citing and referencing in their thesis. Moreover, it will lighten up the endeavour of advisors in guiding the students to produce more qualified thesis. It is indicated by the production of their thesis. Specifically, when inputting metadata on Mendeley desktop, they will be directed to classify type of sources they would like to manage [7]. Therefore, they will be able to recognize what types of sources they may use for their thesis which is an academic project. In addition, the students have their references well-managed and no more missing sources as when it happened to the past students in accomplishing their thesis.

\section{Conclusion}

Based on above findings and discussion, it can be concluded that some of the students have their challenge on the use of Mendeley which is the technical problem such as unsupported program and limited specification of their laptop as well as lack of understanding toward the use of Mendeley when compiling their thesis. Above those technical barriers, most of the students assume that the existence of Mendeley can ease them in citing theories and building references. Particularly for future implication, the findings of this research is expected to spread 
out and read by many readers who have policy on their grabbing hands, so that they can be an agent of quality improvement of students' writing especially to the production of thesis as this is a requirement for students to graduate from their college.

\section{References}

[1] G. Lo Russo, F. Spolveri, F. Ciancio, and A. Mori, "Mendeley: An Easy Way to Manage, Share, and Synchronize Papers and Citations," Plast. Reconstr. Surg., vol. 131, no. 6, 2013.

[2] A. Butros and S. Taylor, "Managing Information: Evaluating and Selecting Citation Management Software, a look at Endnote, Refworks, Mendeley and Zotero," 2010.

[3] S. Haustein and V. Larivière, "Mendeley as a Source of Readership by Students and Postdocs? Evaluating Article Usage by Academic Status," in Proceedings of the IATUL Conferences, 2014.

[4] Z. Zahedi, S. Haustein, and T. D. Bowman, "Exploring Data Quality and Retrieval Strategies for Mendeley Reader Counts," in ASIS\&T SIGMET Workshop on Informetric and Scientometric Research, 2014.

[5] N. Maflahi and M. Thelwall, "How Quickly Do Publications Get Read? The Evolution of Mendeley Reader Counts for New Articles,” J. Assoc. Inf. Sci. Technol., vol. 69, no. 1, pp. 158-167, 2018.

[6] I. Arief and H. Handoko, Mengelola Referensi Publikasi Ilmiah. Padang: LPTIK Universitas Andalas, 2016.

[7] A. Ariyanti, 4 Langkah Mahir Mendeley: Karya Tulis Ilmiah Berkualitas, Prestasi Teratas. Parepare, Sulawesi Selatan: CV. KAAFFAH LEARNING CENTER, 2019.

[8] A. A. Patak and E. Akib, Hindari Plagiat dengan Mendeley: It's Time to Change the Way We Do Research. 2017.

[9] R. Hidayat and A. A. Patak, "Mendeley Impact on Scientific Writing: Thematic Analysis," Int. J. Adv. Sci. Eng. Inf. Technol., vol. 6, no. 5, pp. 657-662, 2016.

[10] M. A. Alrshah, "Mendeley Reference Management Tool: An Introduction," Selangor, 2015. 